\title{
DEVELOPMENT OF GIRL-STUDENTS' PHYSICAL QUALITIES AT EXTRACURRICULAR CHEER-DANCE CLASSES (CHEER-DANCE SHOW)
}

Pyatnickaya D.V.

Kharkov Humanitarian Pedagogical Academy

\begin{abstract}
Purpose: to work out and substantiate methodic of cheer-dance means' usage in extracurricular trainings of girl students. Material: in experiment 450 girl-students of 17-20 years' age participated. Results: we generalized theoretical knowledge and practical experience in selection, content and organization of girl students' physical education. We presented the data of comparative analysis of girl students' physical condition and (sportswomen and not sportswomen). We noted significant interest to physical education, in which the offered methodic is used. It was found that demands in health strengthening can be formed by means of dance kinds of cheer-leading (cheer-dance and cheer-dance show). Conclusions: We have found prospects of girl students' physical education perfection. It permits to work out different variants of realization of educational health related strategy.
\end{abstract}

Key words: girl students, higher educational establishments, fitness, cheer-dance, cheer-dance show, physical qualities, health.

\section{Introduction}

Recent time in Ukraine there have been being observed steady tendency for reduction of health of population and students in particular. It is also paid attention to in governmental document, regulating physical education in higher educational establishments (HEE). It is studied by specialists in physical culture and sports.

For example, in researches $[1,7,9,11,18,30,34]$ it was established that in period of studying in higher educational establishments quantity of special health group students increases up to $5.3 \%$ in the first year and up to $14.4 \%$ in the forth year. Accordingly, we can observe reduction of quantity of main group students: from $84.0 \%$ to $70.2 \%$.

Besides, researches of other authors [11-13, 19-21, 27, 38-44] witness about low level of physical conditions, physical fitness and workability of students. Authors note insufficient level of solution of main physical education tasks. As a result (after graduation) most of graduates are not physically able to fulfill professional duties with proper quality and intensity. So working potential of youth reduces, though social and economical welfare of our country depends on it.

In this connection, one of the most important tasks of physical education in higher educational establishment is strengthening of health, rising of physical fitness and physical condition of students.

A number of authors $[6,10,19,20,25,26,28]$ note decrease of motivation and interest to physical education classes. Results of these researches point at monotonous character of training material, insufficient effectiveness of existing methodic and forms of physical culture trainings. That is why the problem of upgrading of HEE physical education by implementation of innovative approaches to organization of training process, considering students' motivation, is rather important and urgent. Besides new, modern kinds of motor functioning, which would encourage students for physical exercises, require their implementation. That is why urgency of this problem is evident and requires explanation and analysis.

Purpose, tasks of the work, material and methods

The purpose of the research: is to work out and substantiate methodic of cheer-dance means' usage in extracurricular trainings of $1^{\text {st }}-2^{\text {nd }}$ year girl students.

The tasks of the research:

1. To generalize theoretical knowledge and practical experience in selection, content and organization of higher educational girl students' physical education in process of extracurricular classes.

2. To determine girl students' physical condition and physical fitness.

3. To carry out comparative analysis of girl students' physical condition and fitness: group of not sportswomen and group of cheer-dancers (cheer-leading).

() Pyatnickaya D.V., 2015

http://dx.doi.org/10.15561/20755279.2015.0305 
4. To work out and experimentally prove methodic of application of cheer-dance means in extracurricular trainings of girl students.

5. To work out practical recommendations for physical culture teachers on implementation of the offered cheer-dance methodic in physical education process.

The object of the research: physical education of higher educational establishments' girl students in process of extracurricular trainings.

The subject of the researches: methodic of cheer-dance means' application in extracurricular trainings of $1^{\text {st }}-2^{\text {nd }}$ year girl students of higher educational establishments.

The methods of the research: analysis and generalization of literature data on this topic; generalization of advanced experience of specialists in physical education and coaches with the help of talks and questioning; pedagogic observations over competition and training functioning; pedagogic testing (determination of motor skills' level), functional testing of cardio-vascular and respiratory systems; pedagogic experiment; methods of mathematical statistic.

The contingent of the tested: first and second year girl students of Municipal establishment "Kharkov Humanitarian Pedagogical Academy" of Kharkov regional council. In experiment 450 girl students of 17-20 years' age participated.

We formed experimental and control groups. Each group consisted of 27 girl students. Distribution of girl students into groups was fulfilled by results of questioning, devoted to choosing of motor functioning at physical education classes. That is why trainings of experimental group included dance kinds of cheer-leading: cheer-dance and cheer-dance show $[22,34]$. Control group was trained by traditional academic program for HEEs of Ukraine of III-IV accreditation. The research was conducted in stage-by-stage way.

At first stage we realized the following: pedagogic testing; initial testing of physical condition and physical fitness; analysis and generalization of scientific-methodic literature; determination of purpose, tasks, object and subject of the researches; selection of methods of the researches; working out of experimental methodic of training. Experimental methodic of trainings was oriented on reduction of body mass, normalization of metabolism, giving up of harmful habits, improvement of physical condition and general state, on propaganda of healthy life style (HLS) and motivation for physical exercises' practicing. Content of cheer-dance trainings included dance block. This block was built on the base of cheer-leading's basic elements: pirouettes, splits, waving, cheer-jumps, leaps. There were no elements of acrobatics, supports of partner, pyramids. That is why this methodic was quite accessible for girl students. Cheer-dance exercises included movements and musical fragments of different dance styles (jazz, funk, pop, rap, lyrical dance and so on). That is why this kind of cheerleading facilitates not only physical development of girl students' motor skills but also their aesthetic education.

At second stage we conducted pedagogic experiment. It implied that application of cheer-dance means in extracurricular trainings stimulated interest to physical exercises. They were oriented on formation and strengthening of health, perfection of physical condition and fitness.

At third stage we processed the received results and fulfilled comparative analysis of them. It permitted to determine effectiveness of methodic of cheer-dance means' application in extra curricular trainings of higher educational establishments' girl students.

\section{Results of the research}

A number of authors dealt with perfection of physical education in HEEs of different profiles at the account of implementation of training material's optimal content, new forms and means. For example Barybina L.M., Semashko S.A., Kriventsova H.V. [5] worked out system of aerobic trainings with application of individual approach. Mishchenko V.S., Kuehne T., Vinogradov V.E., Melnik L.J., Niewiadomska A. [24] implemented 8- weeks' program of physical exercises, mainly of power character in combination with vibration impact of rotational type. The purpose of such researches is increasing of girl students' power potentials. Zaharova L.V., Lyulina N.V. [15] worked out aerobic experimental methodic with usage of imitation exercises of different kinds of sports. Uskov S.V. [31] regarded problems of preservation and strengthening of schoolchildren's and students' psychic health with the help of martial arts' trainings on example of karate-do. Yasko G.V., Kashuba E.V. [17] implemented Hatha yoga methods in students' learning process. Balamutova N.M., Babadganjan V.V. [4] applied hydro-pedagogic and hydro-kinesio-therapy as mean of students' suffering 
form scoliosis rehabilitation. Kozina Z.L. et al. [19] implemented game-oriented aqua-fitness with application of special technical devices. Voronov M.P., Stolyarenko O.M. [8] studied health related influence of gymnastic exercises with usage of modern computer technologies, oriented on formation of students' correct carriage. Bala T.M. [2, 3] researches influence of cheer-leading exercises on secondary schoolchildren's physical health and motor fitness. Loutsenko L.S. et al. [23] regarded construction of sportsmen's training process in cheer-leading at stage of specialized basic training. Ilnitskaya A.S. et al. [16] studied methodic of physical exercises' training on the base of body-flex and pilates. Fomenko E.V. [32] used innovative methodic of application of nontraditional kinds of gymnastic in extracurricular girl students' trainings and so on.

However, we have not found works, devoted to methodic of cheer-dance trainings and their influence on HEE students' physical condition and physical fitness.

With it, it should be noted that cheer-leading is modern, progressive, spectacular kind of motor functioning. It is becoming still more popular in our country.

This term resulted from English cheer-leading, where "cheer" - call and "lead" - means guide. One of its kinds is cheer-dance (cheer-dance show). It means call for dance (presenting of plot in dance). This is the simplest kind of cheer-leading because it does not require special equipment and large site for trainings. It excites by its movements and attracts modern youth by its show character. It can be practiced both by girls (cheer dance) and by boys (cheer-dance show).

In our opinion usage of specially selected cheer-dance exercises in physical education process will positively reflect on indicators of students' physical condition and physical fitness, increase their interest to physical trainings. That is why there is an urgent demand in working out of methodic of cheer-dance means' usage in girl students' physical education.

The largest reserves of application of such means belong to effective organization of health related physical culture functioning of girl students, especially in extracurricular classes [21, 29, 33]. However, physical education trainings with usage of modern technologies (in particular cheer-dance) differ from traditional. These trainings require provisioning of students with the newest modern information about health; lead to increased organism's energy losses. Results of the researches determine dominating preferences of students to training of different kinds of physical exercises.

Practical significance of our research is in working out of methodic of cheer-dance movements' usage, their rational application in girl students' extracurricular trainings. It permits to improve their physical condition, physical fitness and interest to physical culture trainings. Besides, the received materials can be used for formation and preparation of students' cheer-dance (cheer-dance show) teams for competitions of different levels.

\section{Discussion}

Results of testing of experimental group's girl students witness about their higher indicators in comparison with control group (see table 1).

Table 1

Confidence of indicators of first and second year girl students of experimental group

\begin{tabular}{|l|l|l|l|l|l|}
\hline № & \multicolumn{1}{|c|}{$\begin{array}{c}\text { Indicators } \\
\text { In=27) }\end{array}$} & $\begin{array}{c}\text { 19-20 years' age } \\
(\mathbf{n = 2 7})\end{array}$ & \multicolumn{1}{|c|}{ p } & t \\
\hline \multicolumn{6}{|c|}{ Indicators of physical condition } \\
\hline 1 & Mass, kg & $56.4 \pm 2.6$ & $60.7 \pm 2.9$ & $<0.05$ & 2.13 \\
2 & Vital capacity of lungs (VCL), cm ${ }^{3}$ & $2950 \pm 96.3$ & $2770 \pm 101.7$ & $<0.05$ & 1.28 \\
3 & Heart beats' rate (HBR) b.p.m. & $69.1 \pm 1.46$ & $69.6 \pm 1.84$ & $<0.05$ & 0.25 \\
\hline \multicolumn{7}{|c|}{ Physical fitness } \\
\hline 1 & Quantity of jumps per 20 sec, times & $61.4 \pm 2.81$ & $59.2 \pm 3.12$ & $<0.05$ & 0.3 \\
3 & Flexibility, cm & $13.32 \pm 1.84$ & $9.97 \pm 2.03$ & $<0.05$ & 1.22 \\
\hline
\end{tabular}


Implementation of new kind of motor functioning (cheer-dance) resulted in girl students' higher load on cardio-vascular and respiratory systems. In experimental group's students pulse insignificantly increased. In control group HBR was much higher. Speed of motor response was assessed with test for speed of seizing of falling stick with stronger hand. The test's results showed that quality of this test's fulfillment reduced quicker in experimental group (19-20 years' age). In first group this indicator was $9.86 \pm 0.86 \mathrm{sec}$. In older group it was $13.2 \pm 1.02 \mathrm{sec} .(\mathrm{t}=2.51)$. Change of flexibility was assessed by forward torso bent from sitting position. Speedpower endurance was measured by maximal quantity of jumps from the spot during $20 \mathrm{sec}$. In older group this indicator was less a little (see table 1).

Thus, comparative analysis of experimental group girl students' physical condition and physical fitness showed significant changes in their organisms in comparison with girl students of control group.

In our work we supplement and specified results of researches of V.P. et al. [14, 45], Iermakov S.S. et al. [11], Kozina Zh.L. et al. [19], Fomenko E.V. [32], Adashevskiy V.M. et al. [35], Buultjens M. и Robinson P. [36], Highstreet V.D. [37] et al. about advantages of physical education trainings with application of modern technologies in comparison with traditional trainings. Such trainings are accompanied by higher interest of students. They give students information about health and means of increasing of organism's energy consumption.

The received results showed girl students' dominating preferences of different kinds of physical exercises. Besides, we supplemented data base about specificities of cheer-dance exercises' training.

In our research conception of Krucevich T.I. [21] about importance of development and application of innovative technologies in students' physical education is further developed as well as conceptions of Kozina Z.L. and Iermakov S.S. [20] about purposefulness of working out and application of non-traditional systems in students' physical education.

\section{Conclusions:}

1. Implementation of substantiated methodic of cheer-dance trainings permits for girl students to significantly improve physical fitness, physical conditions and functional state of their organisms.

2. The worked out practical recommendations can be used in educational process of physical culture institutions, physical education faculties of pedagogic universities, higher physical culture establishments especially in studying of disciplines: theory and methodic of aerobic training, sportpedagogic perfection, and as an independent component. Besides they can be used as a supplement to existing educational systems, working out of learning and methodic manuals.

It is recommended to direct further researches to finding of changes in girl students' physical condition after application of the offered cheer-dance methodic. Besides, they shall be pointed at studying of comparative characteristics of physical condition and physical fitness of $3^{\text {rd }}$ and $4^{\text {th }}$ year girl students, practicing cheer-dance.

\section{Acknowledgement}

The researches have been conducted in compliance with "Combined plan of scientific-research works in sphere of physical culture and sports for 2011-2015" by topic 2.4 "Theoretical-methodic principles of individualization in physical education and sports" (state registration number 0112U002001). The researches were fulfilled in compliance with scientific-research works at the account of governmental budget of Ministry of education and science of Ukraine for 2014-2015 "Theoretical-methodic principles of application of informational, pedagogic and medical-biological technologies for formation of healthy life style" (state registration number 0113U002003) and "Theoretical-methodic provisioning of formation of personality's healthy life style in conditions of educational establishment in context of European integration" (state registration number $0114 \mathrm{U} 001781$ ).

\section{Conflict of interests}

The author declares that there is no conflict of interests.

\section{References}

1. Arefiev VG. Modeling of differentiated physical fitness in school children. Pedagogics, psychology, medical-biological problems of physical training and sports, 2014;1:3-8. http://dx.doi.org/10.6084/m9.figshare.894383 
2. Bala TM. The influence of cheerleading exercises on the schoolchildren's physical health of 5-9th forms. Pedagogics, psychology, medical-biological problems of physical training and sports, 2012;4:12 - 16.

3. Bala TM. Kompleksna ocinka vplivu vprav cherlidingu na fizichne zdorov'ia ta rukhovu pidgotovlenist' shkoliariv serednikh klasiv. Cand. Diss. [Complex assessment of cheer-leadin exercises' influence on physical health and motor fitness of secondary schoolchildren. Cand. Diss.]. Kharkov, 2013.

4. Balamutova NM, Babadganjan VV. Hydro aerobics as means for physical state improvement of female students. Pedagogics, psychology, medical-biological problems of physical training and sports, 2013;3:3-6. http://dx.doi.org/10.6084/m9.figshare.644731

5. Barybina LM, Semashko SA, Kriventsova HV. Features of organization of sport mass work at the technical higher institution. Physical Education of Students, 2011;1:18-22.

6. Bubka SN. The role of Alexey Butovsky in the development of physical education, sport and Olympic Movement. Pedagogics, psychology, medical-biological problems of physical training and sports, 2012;9:58.

7. Vas'kov YV. Acmeological approach to physical education of students of secondary schools in the aspect of personality-oriented training. Pedagogics, psychology, medical-biological problems of physical training and sports, 2015;3:3-9. http://dx.doi.org/10.15561/18189172.2015.0301

8. Voronov MP, Stolyarenko OM. Influence of physical exercises on students with violation of organs of sight. Physical education of students, 2010;6:13-15.

9. Gryban GP. The evaluation of the efficiency of introducing the model of the methodical system of physical education of agrarian students. Pedagogics, psychology, medical-biological problems of physical training and sports, 2012;11:27-30. http://dx.doi.org/10.6084/m9.figshare.97350

10. Dovhanyk MS, Chychkan OA, Sirenko RR. Parameters of alpha - rhythm in the students who practise curative running. Pedagogics, psychology, medical-biological problems of physical training and sports, 2012;5:59-62.

11. Iermakov SS, Apanasenko GL, Bondarenko TV, Prasol SD. Physical culture as the main tool of health's culture. Pedagogics, psychology, medical-biological problems of physical training and sports, 2010;11:31 33 .

12. Iermakova TS. Forming a health culture of future teachers in Polish educational establishments. Physical Education of Students, 2014;5:14-19. http://dx.doi.org/10.15561/20755279.2014.0503

13. Iermakova TS. Education of children in Polish family in a context of forming health culture. Pedagogics, psychology, medical-biological problems of physical training and sports, 2014;11:17-22. http://dx.doi.org/10.15561/18189172.2014.1104

14. Zajcev VP, Iermakov SS., Prusik Kr. Physical recreation in structure of students' active rest. Physical education of students, 2011;1:68-77.

15. Zaharova LV, Lyulina NV. Basis of integrated approach to sports and recreational activities of students of special medical groups. Physical Education of Students, 2014;1:17-21. http://dx.doi.org/10.6084/m9.figshare.903688

16. Ilnitskaya AS, Kozina ZL, Lakhno EG, Ilnitskaya LV, Cieślicka Mirosława, Stankiewicz Błaźej, Pilewska Wiesława. Students' attitude to the possibility of applying modern information and communication technologies in the educational process in physical education. Physical Education of Students, 2014;2:18-24. http://dx.doi.org/10.6084/m9.figshare.906369

17. Yasko GV, Kashuba EV. Innovation sports and health areas in universities supporting basis orientation. Physical education of students, 2011;3:116-118.

18. Kozhevnikova LK. Professional-applied pedagogical teaching of junior school future teachers to working activity. Physical Education of Students, 2012;3:49-52.

19. Kozina ZL, Iermakov SS, Bazilyuk TA, Voloshina E. Innovative technologies of aquafitness of playing orientation with the use of technical devices in physical education of students. Physical education of students, 2012;1:42-46. 
20. Kozina ZL, Iermakov SS. Analysis of students' nervous system's typological properties, in aspect of response to extreme situation, with the help of multi-dimensional analysis. Physical Education of Students, 2015;3:10-19. http://dx.doi.org/10.15561/20755279.2015.0302

21. Krucevich TI, Bezverkhnia GV. Rekreaciia u fizichnij kul'turi riznikh grup naselennia [Recreation in physical education of different population groups], Kiev: Olympic Literature; 2010. (in Ukrainian)

22. Lisickaia TS. Aerobika na vse vkusy [Aerobics to all tastes]. Moscow: Education, 1994. (in Russian)

23. Loutsenko LS, Zinchenko IA, Luchko OR, Shepelenko TV. Construction of annual cycle of preparation of sportsmen, specialized in cheerleading. Physical education of students, 2011;6:62-66.

24. Mishchenko VS, Kuehne T, Vinogradov VE, Melnik LJ, Niewiadomska A. The effects of health-related physical training combined with whole body vibration (vibration platform) on strength capacities of young females. Physical Education of Students, 2012;1:75-83.

25. Moskalenko NV, Kovtun AA. Influence of physical culture and sport on the psychophysiological state of students. Physical Education of Students, 2012;3:83-86.

26. Nosko MO, Iermakov SS, Garkusha SV. Theoretical and methodological aspects of strengthening physical health of pupils and students. Visnik Chernigivs'kogo nacional'nogo pedagogichnogo universitetu, 2010;76:243-247. (in Ukrainian)

27. Popichev M.I. Complex diagnostics and estimation of health of students level. Physical Education of Students, 2011;3:71-76.

28. Roters TT. Physical improvement of students during interactive physical and aesthetic education. Physical Education of Students, 2013;4:72-76. http://dx.doi.org/10.6084/m9.figshare.663624

29. Serhiyenko LP, Lyshevska VM. Soles dermatoglyphics in the prognosis of sports endowment: differences of soles dermatoglyphics in sportsmen of different sport kinds. Pedagogics, psychology, medical-biological problems of physical training and sports, 2013;3:57-61. http://dx.doi.org/10.6084/m9.figshare.644738

30. Timoshenko OV. Simulation technology achievement of students in physical education classes. Physical Education of Students, 2010;3:102 - 105.

31. Uskov SV. Formation of stress students in the process of notions of martial arts in high school. Physical Education of Students, 2013;5:88-92. http://dx.doi.org/10.6084/m9.figshare.771216

32. Fomenko EV. Practical recommendations for the implementation of health technologies to enhance physical fitness of students in extracurricular classes during non-traditional gymnastics. Pedagogics, psychology, medical-biological problems of physical training and sports, 2014;7:31-36. http://dx.doi.org/10.6084/m9.figshare.1015385

33. Furman YM, Salnikova SV. Improvement of aerobic energy supply processes in 37-49 yrs old women by means of complex aqua-fitness trainings' and methodic of endogenous - hypoxic breathing's application. Pedagogics, psychology, medical-biological problems of physical training and sports, 2015;7:59-63. http://dx.doi.org/10.15561/18189172.2015.0708

34. Shkola OM. Teoriia ta metodika navchannia [Theory and methodic of training]. Kharkov: FOP Brovin O.V., 2014. (in Ukrainian)

35. Adashevskiy VM, Iermakov SS, Firsova IuIu. Physical mathematical modelling of difficult elements of acrobatic rock-and-roll. Physical Education of Students, 2013, vol.3, pp. 3-10. http://dx.doi.org/10.6084/m9.figshare.662463

36. Buultjens M, Robinson P. Enhancing aspects of the higher education student experience. Journal of Higher Education Policy and Management. 2011;33(4):337-346. http://dx.doi.org/10.1080/136008 0X.2011.585708.

37. Highstreet VD. Aerobics for All Ages: A Broadband Approach to a Diverse University Population. Journal of American College Health. 1983;32(3):125-127. http://dx.doi.org/10.1080/07448481.1983.9936156.

38. Iermakov SS. Bio-mechanical models of strike movements in context of perfection of sportsmen technical fitness. Teoria ta metodika fizicnogo vihovanna, 2010;4:11-18. (in Ukrainian)

39. Iermakov SS, Kriventsova IV, Minenok AA. Peculiarities of physical training of special health group students in pedagogic HEE. Visnik Chernigivs'kogo derzhavnogo pedagogichnogo universitetu, 2013;107(2):193-197. (in Russian) 
40. Ivashchenko OV, Khudolii OM, Yermakova TS, Pilewska W, Muszkieta R, Stankiewicz B. Simulation as

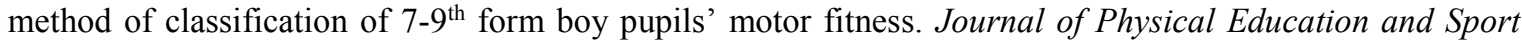
(JPES), 2015;15(1):142-147. http://dx.doi.org/10.7752/jpes.2015.01023

41. Ivashchenko OV, Yermakova TS, Cieslicka M, Zukowska H. Discriminant analysis in classification of motor fitness of 9-11 forms' juniors. Journal of Physical Education and Sport (JPES). 2015;15(2):238-244. http://dx.doi.org/10.7752/jpes.2015.02037

42. Khudolii OM, Iermakov SS, Prusik K. Classification of motor fitness of 7-9 years old boys. Journal of Physical Education and Sport (JPES), 2015;15(2):245-253. http://dx.doi.org/10.7752/jpes.2015.02038

43. Klimenchenko VG, Kriventsova IV, Gorban' IIu, Makhonin IM. Features of the procedure of joint exercises for physical education with students of basic and special medical groups. Pedagogics, psychology, medicalbiological problems of physical training and sports, 2014;4:18-21. http://dx.doi.org/10.6084/m9.figshare.950951

44. Prusik Krzysztof, Prusik Katarzyna, Kozina ZhL, Iermakov SS. Features of physical development, physical preparedness and functional state of boys and girls - students of Polish higher educational establishments. Physical Education of Students, 2013;1:54-61. http://dx.doi.org/10.6084/m9.figshare.96415

45. Zaycev VP, Iermakov SS, Manycharyan SV, Fedyay IA. Recreation as a scientific discipline and its historical aspects. Pedagogics, psychology, medical-biological problems of physical training and sports, 2012;12:46-52. http://dx.doi.org/10.6084/m9.figshare.105444 


\section{Information about the author:}

Pyatnickaya D.V.; http://orcid.org/0000-0001-9972-8402; matushkadariya@mail.ru; Kharkov Humanitarian Pedagogical Academy; Sh. Rustaveli alley 7, Kharkov, 61000, Ukraine.

Cite this article as: Pyatnickaya D. V. Development of girl-students' physical qualities at extracurricular cheer-dance classes (cheer-dance show). Physical education of students, 2015;4:31-38. http://dx. doi. org/10. 15561/20755279. 2015. 0405

The electronic version of this article is the complete one and can be found online at: http://www. sportpedu. org. ua/html/arhive-e. html

This is an Open Access article distributed under the terms of the Creative Commons Attribution License, which permits unrestricted use, distribution, and reproduction in any medium, provided the original work is properly cited

(http://creativecommons. org/1icenses/by/3.0/deed. en).

Received: 16.08.2015

Accepted: 16.08.2015; Published: 30.08.2015 